\title{
IBAPICHUNA: AN EDIBLE DACRYODES (BURSERACEAE) FROM THE NORTHWEST AMAZON
}

\author{
JAMES L. ZARUCCHI*
}

It has recently been found that the fruits of Dacryodes belemensis Cuatr. (Burseraceae) are of use to the Kubeo Indians of the Colombian Vaupés. The fruits of this tree, known locally as "Ibapichuna," are employed to make a beverage. Utilization of this species came to light during recent field work in Colombia and Brazil (1979) while I was studying several apocynaceous genera which yield edible fruits. The principal observations were made during a short stay on the Río Kubiyú, an affluent of the Río Vaupés about $50 \mathrm{~km}$. upriver from the town of Mitú (capital of the Comisaría del Vaupés), at approximately $1^{\circ} 03^{\prime} \mathrm{N}$. Lat., $70^{\circ} 16^{\prime} \mathrm{W}$. Long. ${ }^{1}$ This part of the Colombian Amazonia is adjacent to the Brazilian State of Amazonas. Prior to the present century, this portion of the Vaupés, below the Raudal de Yuruparí ("Devil's Cataract" $-0^{\circ} 50^{\prime} \mathrm{N}$. Lat., $70^{\circ} 34^{\prime}$ W. Long.) on the Río Vaupés, was claimed by Brazil.

During my stay on the Río Kubiyú, the inhabitants prepared several fruits which supplemented the usual diet of tapioca (from Manihot esculenta), game, and fish. For the most part, these fruits included those of the palms Jessenia Bataua and either Oenocarpus or Euterpe. A fruit unfamiliar to me was collected which the natives know as "Ibapichuna." The name comes from Tupi-Guaraní (Lengoa Gêral or Nhengatú) meaning black fruit: iba-fruit; pichû-black (Ruiz, 1876). The fruits were similar in appearance to those of the palms, but they had a green resinous pulp covering a hard endocarp, rather than the pinkto-purple oily pulp characteristic of the palms. It was possible to

\footnotetext{
*Botanical Museum and Department of Biology, Harvard University, Cambridge, MA 02138.

${ }^{1}$ Previous studies in 1975 and 1976 were carried out in the same region, primarily on members of the Apocynaceae and other plants of economic interest.
} 
gather specimens from a nearby tree which had been felled that very day for its ripe fruit. A duplicate of that collection (Zarucchi 2487) was sent to the Smithsonian Instititution, where it was determined as the second known collection of Dacryodes belemensis Cuatr. ${ }^{2}$ Dr. José Cuatrecasas, who made the identification, has said that my voucher collection "coincides perfectly with the type specimen [Pires s.n. holotype US] in outlines, texture, size and color" (Cuatrecasas, pers. comm.). He also mentioned that the use of the fruits by indigenous peoples "indicates that the species is less rare than the scarcity of botanical specimens might suggest." Conversations with several botanists (R.E. Schultes, J. Cuatrecasas, and H. García-Barriga), familiar with the Río Kubiyú and/or adjacent areas of the Colombian Vaupés, have failed to turn up specimens or additional observations regarding the food use or occurrence of Dacryodes.

Dacryodes is a pantropical, dioecious member of the Burseraceae which was first described by Vahl in 1810, based upon a collection from Puerto Rico (Cuatrecasas, 1957; Lam, 1932). The majority of the species, as the genus is presently accepted, occur in Africa and Asia (sections Pachylobus and Tenuipyrena). The twenty neotropical species are assigned to the wholly American section Dacryodes. The most recent revision of this section by Cuatrecasas (1957) comprises fifteen species and two varieties; five additional species have been described since Cuatrecasas' publication (fide: Gray Herbarium Cards). Species of sect. Dacryodes are known from widespread areas in tropical America: from the Caribbean Islands to scattered localities in northern South America. Most species are known from only a few collections; some are represented solely by fruiting specimens.

My collection (2487) appears to represent the second one of Dacryodes belemensis and was found some $2450 \mathrm{~km}$. from the type locality: "Brazil: Belém em terras do Inst. Agron. de Norte (Reserva de floresta nativa), Horto Mucambo, arvore no. 10-18,

${ }^{2}$ Specimens of Zarucchi 2487 have been deposited in the herbarium of the Instituto de Ciencias Naturales, Universidad Nacional de Colombia, Bogotá (COL); the Gray Herbarium of Harvard University (GH); and the United States National Herbarium (US). Additional duplicates will be distributed from $\mathrm{COL}$ and $\mathrm{GH}$. 
J. M. Pires (holotype, US)." No flowering material is yet available for this species. The voucher collection for this study was made on July 16, 1979, near the end of the rainy season. The specimens were collected from a tree $15 \mathrm{~m}$. tall; the trunk was clear of branches for about two-thirds of its height. The tree has alternate imparipinnate (usually 2- to 3-jugate) compound leaves with axillary inflorescences. The mature fruits are oblongellipsoid, about $20-25 \mathrm{~mm}$. long and $13 \mathrm{~mm}$. in diameter.

Natives of the Río Kubiyú, with whom I spent several weeks, provided the following information regarding "Ibapichuna." It is a medium-sized tree of the forest understory, said to be relatively rare in mature forests, found growing on non-inundated sandy soil. Furthermore, it is reported that not all of the trees produce fruit, suggesting that the species is dioecious. The local inhabitants claim that it flowers in February or March.

The manner of fruit collection is destructive. Trees are felled, and all of the mature fruits (deep violet to black) are gathered and carried back to the habitation in a woven palm leaf basket. The trees that are felled are visited repeatedly over several weeks as additional fruits become mature. ${ }^{3}$ A normal tree yields 3 to $4 \mathrm{~kg}$. of fruit in the initial gathering. No use is made of the wood, but it was pointed out that the trees produce a resin which can be used for torches. After the fruits are washed thoroughly, they are put into a large vessel, covered with water, and placed over a fire to heat slowly to near the boiling point; this takes approximately 30 minutes. The fruits can now be eaten, but they are usually crushed and extracted to prepare an after-dinner beverage. To make this drink, the warm fruits are placed upon a loosely woven sieve basket, with an appropriate container below to catch the extracted pulp. The fruits are then crushed by hand, and warm water is repeatedly added to the mass of pericarp, pulp, and bony endocarp to extract the green pulp. The kneading process continues until most of the pulp has passed through the sieve. The resulting liquid is a resinous, bright green beverage with an appearance similar to thin spinach purée.

\footnotetext{
${ }^{3}$ This repeated gathering of fruits from a felled tree has previously been observed by the author in the case of Couma macrocarpa Barb. Rodr. (Apocynaceae), known in the Colombian Amazon as "Juansoco" and as "Sorva" in Brazil.
} 
I found the drink difficult to imbibe. My informant, Sr. Miguel Triana, stated that not everyone partakes of the beverage; the resinous quality is not universally enjoyed. The heated fruits are more palatable, although they have a sharp, tangy taste. The fruit is crushed between the tongue and the roof of the mouth, and the creamy-smooth, slightly fibrous pulp is extracted by the tongue from between the crisp exocarp and the bony endocarp. These latter parts are then expelled from the mouth. Much practice is necessary to accomplish this maneuver with ease.

A collection by Cardona (Cardona 2364-Dacryodes peruviana var.caroniensis) reports that the fruits are eaten by the Arekuna Indians of Venezuela: “. . . arbol $30 \mathrm{~m}$. cuyo fruto llamado 'urá' es comido por los Arekunas" (Cuatrecasas, 1957). Lam(1932), in his study of the Burseraceae for southeast Asia, mentions in the discussion of Darcyodes rostrata that "the fruits are said to be very bitter to the taste, although a Luzon specimen mentions that they are eatable." Uphof (1968) states that Dacryodes edulis from tropical West Africa has edible fruits that are consumed by the natives. Additional uses of Dacryodes described by Uphof include the utilization of woods in construction and the extraction of resins. In 1965, Sandwith described Dacryodes trinitensis from Trinidad. This species which he compared with Dacryodes excelsa (a widespread West Indian species) and Dacryodes belemensis, was observed by Dr. D. W. Snow as being one of the most important sources of food for the Oilbird (Steatornis caripensis). A discussion of the fruits and their food value, as well as the role that the Oilbirds might play in the dispersal of the Dacryodes fruits is presented by Sandwith (1965).

The observation of the role of Dacryodes belemensis as a food source therefore complements previous studies of other members of the genus and suggests directions for future study of this littleknown tropical species.

\section{ACKNOWLEDGMENTS}

I wish to thank the Director and Staff of the Instituto de Ciencias Naturales, Universidad Nacional de Colombia(Bogotá) through which my field work was conducted, with the permission of INDERENA. Funding for field studies in 1979 (Colombia and 
Brazil) was provided by the Atkins Garden Fund of Harvard University and the National Science Foundation (NSF Grant INT78-23341: G. T. Prance, Principal Investigator). Special thanks are due to Dr. Roberto Jaramillo M. of the Instituto de Ciencias Naturales, Sr. Miguel Triana of the Río Kubiyú, and Dr. José Cuatrecasas of the Smithsonian Institution.

\section{PRINCIPAL WORKS CONSULTED}

Cuatrecasas, J. 1957. The American Species of Dacryodes. Trop. Woods 106: 46-65.

Kalkman, C. 1954. Revision of the Burseraceae of the Malaysian Area in a Wider Sense VIa, VII-IX. Blumea 7(3): 498-552.

Lam, H. J. 1932. The Burseraceae of the Malay Archipelago and Peninsula. Bull. Jard. Bot. Buitenzorg, sér. 3, 12(3-4): 281-560.

Leenhouts, P. W., C. Kalkman, and H. J. Lam. 1955. Burseraceae. Flora Malesiana, ser. 1, 5(2): 209-296.

Ruiz de Montoya, P. A. 1876. Arte de la Lengua Guarani, ó mas bien Tupi (Gramatica y Diccionarios). Faesy \& Frick, Vienna.

Sandwith, N. Y. 1965. Contributions to the Flora of Tropical America; LXXV - A New Dacryodes in Trinidad. Ann. Missouri Bot. Gard. 52(3): $434-437$.

Uphof, J. C. Th. 1968. Dictionary of Economic Plants. Second edition. Verlag von J. Cramer, Lehre. 


\section{$2 \mathrm{BHL}$ Biodiversity Heritage Library}

Zarucchi, James Lee. 1980. "Ibapichuna: an Edible Dacryodes (Burseraceae) from the Northwest Amazon." Botanical Museum leaflets, Harvard University 28(1), 81-85. https://doi.org/10.5962/p.168643.

View This Item Online: https://www.biodiversitylibrary.org/item/31875

DOI: https://doi.org/10.5962/p.168643

Permalink: https://www.biodiversitylibrary.org/partpdf/168643

\section{Holding Institution}

Missouri Botanical Garden, Peter H. Raven Library

\section{Sponsored by}

Missouri Botanical Garden

\section{Copyright \& Reuse}

Copyright Status: Public domain. The BHL considers that this work is no longer under copyright protection.

This document was created from content at the Biodiversity Heritage Library, the world's largest open access digital library for biodiversity literature and archives. Visit BHL at https://www.biodiversitylibrary.org. 